\title{
Chronic muscular Pain treatment with Muscular Acoustic Modulator Device in elderly
}

\author{
S Mandolesi', D Mandolesi, F Ciciarello \\ From de Senectute: Age and Health Forum \\ Catanzaro, Italy. 5-7 December 2009
}

\section{Background}

Muscles Contractures are an important part of multifactorial etiology of chronic pain.

$\mathrm{MAM}^{\circ}$ is an acoustic waves device modulated in power and frequency $(0-50 \mathrm{~Hz}, 0-5 \mathrm{Bar})$ for treatment of muscular contractures.

If the treatment of the chronic muscular contractures with $\mathrm{MAM}^{\circ}$ can improve quality life in elderly.

\section{Materials and methods}

We have analyzed the results of a comprehensive examination of 5 over 60 age patients (Group 1: aged $76+/-5,2$ years) and 5 control over 60 age patients (Group 2; aged $74+/-2,2$ years). Every group was studied with a manual objective examination of the skeletal muscle apparatus to find perceived and evoked contractures reported on a paper map support. This map allows to transfer with accuracy to the physiotherapist which are the points on which he must make $\mathrm{MAM}^{\bullet}$ treatment.(Group 1: contractures 22,8 +/-1,47; Group 2: contractures 23,4 $+/-2,03)$. To each group was given a BPI-sf (Brief Pain Inventory) to have a review of quality life the first day of examination and at the last day of treatment. Group 1 was treated with an acoustic wave modulator device

Table 1

\begin{tabular}{lllllll}
\hline & N. pts. & Aged & Contracture points I treatment & Contracture points IV treatment & BPI before & BPI after \\
\hline Group 1 & 5 & $76+/-5,2$ years & $22,8+/-1,47$ & $6,8+/-2,7$ & $5,8+/-3,46$ & $0,5+/-0,93$ \\
Group 2 & 5 & $74+/-2,2$ years & $23,4+/-2,03$ & $24,2+/-1,42$ & $6,4+/-1,27$ & $6,2+/-2,66$ \\
\hline
\end{tabular}

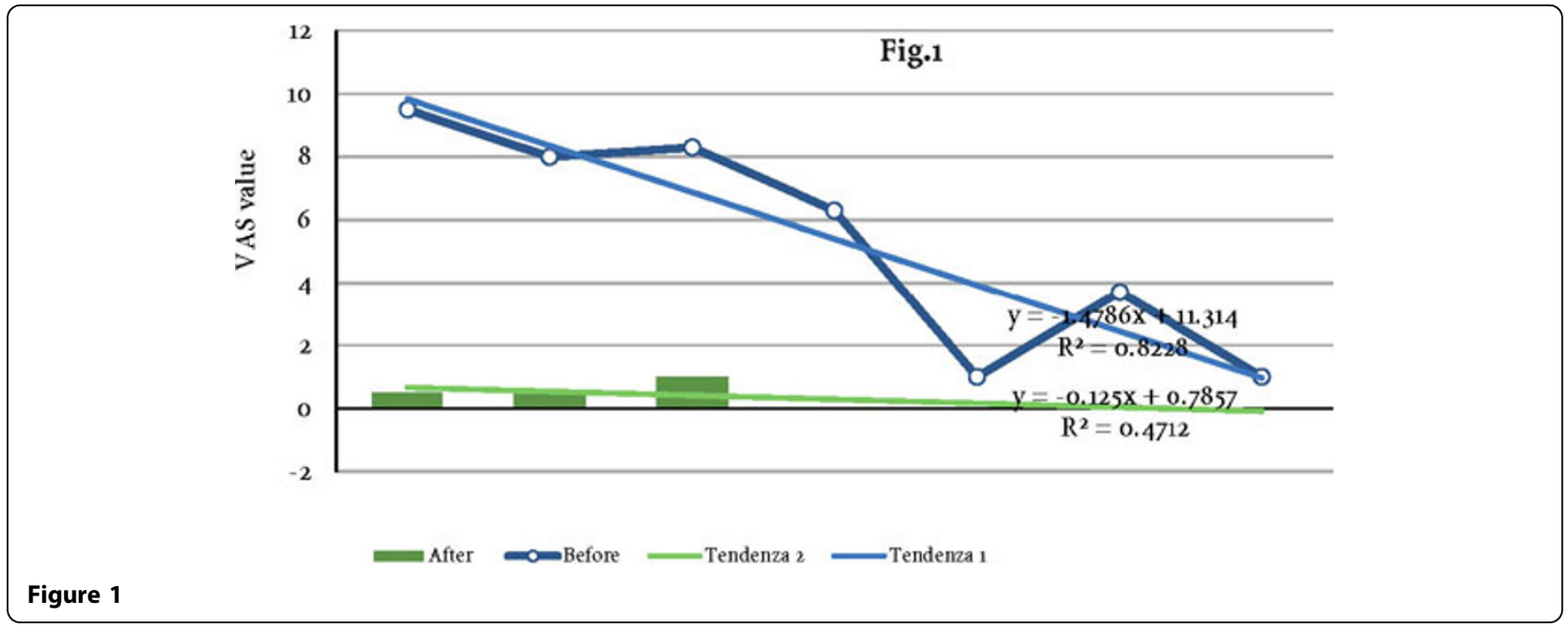

Cardiovascular Department, La Sapienza University of Rome, Italy 
$\left(\mathrm{MAM}^{\circ}\right)$, once a week, for four weeks. Each point was treated three times every sitting (16 sec for point). Group 2 was not treated

\section{Results}

We have observed in Group 1 a reduction of contracture points after IV treatment with $\mathrm{MAM}^{\circ}$ and an improvement of quality life value with BPI test taking average of all the averages of VAS respect Group two, as shown in Table 1 and Figure 1.

\section{Conclusions}

Treatment of chronic muscular pain with acoustic $\mathrm{MAM}^{\circ}$ device reduces VAS value in BPI from $5,8+/-3,46$ to $0,5+/-0,93$, reduces of $70 \%$ muscular contractures and improve quality life in elderly.

Published: 19 May 2010

doi:10.1186/1471-2318-10-S1-A111

Cite this article as: Mandolesi et al: Chronic muscular Pain treatment with Muscular Acoustic Modulator Device in elderly. BMC Geriatrics 2010 10(Suppl 1):A111.
Submit your next manuscript to BioMed Central and take full advantage of:

- Convenient online submission

- Thorough peer review

- No space constraints or color figure charges

- Immediate publication on acceptance

- Inclusion in PubMed, CAS, Scopus and Google Scholar

- Research which is freely available for redistribution

Submit your manuscript at www.biomedcentral.com/submit 